\title{
THE EFFECTIVENESS OF ACCOUNTING E-MODULE INTEGRATED WITH CHARACTER VALUE TO IMPROVE STUDENTS' LEARNING OUTCOMES AND HONESTY
}

\author{
Destri Sambara Sitorus*, Siswandari, Kristiani \\ Teacher Training and Education Faculty, Universitas Sebelas Maret \\ *e-mail: destri.sambara@gmail.com
}

\begin{abstract}
This study was aimed to examine the effectiveness of e-accounting module integrated character values to improve students' learning outcomes and honesty. This was motivated by lack of students' understanding of accounting materials so that students tended to take dishonest actions like cheating while doing assignments or examinations. Honesty is one of the characters developed in many curriculla, so that honest character needs to be integrated in learning activities. The data collected in this study were the data on students' learning outcomes collected through multiple choice tests and the data on students' honesty collected through questionnaires. Students' learning outcomes data were analyzed through independent sample t test and the data on students' honesty were analyzed descriptively by narrative. The t-test results obtained sig values $0.014<0.05$ so that there were significant differences between the learning outcomes of the experimental class and the control class. The results of the questionnaire analysis showed that the students' honesty level of the experimental class was in a very good category and the control class was in the good category.
\end{abstract}

Keywords: e-module, character value, honesty

\section{KEEFEKTIFAN E-MODULE AKUNTANSI TERINTEGRASI NILAI KARAKTER UNTUK MENINGKATKAN HASIL BELAJAR DAN KEJUJURAN SISWA}

\begin{abstract}
Abstrak: Penelitian ini bertujuan untuk menguji keefektifan $e$-module akuntansi terintegrasi nilai karakter untuk meningkatkan hasil belajar dan kejujuran siswa. Hal ini dilatarbelakangi oleh kurangnya pemahaman siswa akan materi akuntansi sehingga siswa cenderung melakukan tindakan tidak jujur seperti mencontek pada saat mengerjakan tugas atau ujian. Kejujuran merupakan salah satu karakter yang dikembangkan dalam kurikulum sehingga karakter jujur perlu untuk diintegrasikan di dalam kegiatan pembelajaran. Data yang dikumpulkan di dalam penelitian ini adalah data hasil belajar siswa yang dikumpulkan melalui tes pilihan ganda dan data mengenai kejujuran siswa yang dikumpulkan melalui angket. Data hasil belajar siswa dianalisis melalui uji independent sample t-test dan data mengenai kejujuran siswa dianalisis secara deskriptif naratif. Hasil uji t didapat nilai sig $0,014<0,05$ sehingga terdapat perbedaan yang signifikan antara hasil belajar kelas eksperimen dan kelas kontrol. Hasil analisis angket menunjukkan bahwa tingkat kejujuran siswa kelas eksperimen berada dalam kategori sangat baik dan kelas kontrol berada dalam kategori baik.
\end{abstract}

Kata Kunci: e-module, nilai karakter, kejujuran.

\section{INTRODUCTION}

Thomas J. Stanley in his book titled The Millionaire Mind stated that the main key of someone's success is honesty, then discipline, working together, a solid team work, and working harder than the others. 
In general, honesty is defined as a human's quality in stating and doing the right and appropriate things. Honesty is someone's attitude expressed by words or behaviours reflecting the real situation (Wijaya, 2011). Being honest in daily life gives positive effect to ourselves and others. Being accustomed to be honest will make us trusted by others, have more friends or relations, feel calm and peace. Being honest also creates the harmonity in the society.

Honesty is very important to be applied in school as the character of Indonesian children today (Kesuma, Trianta, \& Premana, 2012). Being honest can be seen from daily activities in the classroom. For example, when the children do a test, they cheat a lot to get a good score. In fact, cheating is a kind of dishonesty to themselves, friends, teachers, and parents. Zulkhairi (2011) stated that honesty is a soul of education and human's life so that learning provcess should run honestly, whether it is from students, teachers, headmasters, and the environment. Honesty is very important in education and social life so that the Indonesian government puts the aspect of honest character in strengthening the implementation of character education in the 2013 curriculum, like the other countries. Curriculum Center of the Indonesian Ministry of National Education identifies 18 character values consisting of religion; pancasila; culture; and the purpose of national education consisiting of religion, tolerance, frienship, loving peace, environmental care, being honest, honesty, appreciating achievement, social care, discipline, democracy, spirit of nationality, loving the homeland, working hard, being creative, being independent, curiosity, and reading a lot (PP No. 19 Tahun 2017).

One of the students' dishonesties occurs when doing tests. Integrity Index of National Examination (IIUN) is an index showing the school and students' honesty level in the implementation of national examination. The following table is the data of IIUN in Vocational High School $(S M K)$ :

Table 1. Results of Integrity Index of National Examination

\begin{tabular}{cc}
\hline Year & IIUN \\
\hline 2013 & 60.25 \\
2014 & 61.43 \\
2015 & 62.98 \\
2016 & 65.05 \\
2017 & 69.15 \\
\hline
\end{tabular}

The data showed that the honesty level in the implementation of national examination of vocational school students in Indonesia was still at the low category although there was an improvement of honesty level in the implementation of national examination every year. Besides, the result of the survey conducted at Vocational High School " $X$ " which was one of the state vocational high schools in Surakarta showed that $52 \%$ or 56 students out of 106 students of class X Accounting cheated during the examination. The survey was conducted by giving closed questionnaire to the students containing the questions related to honesty in the learning process. Based on the interview, the students cheated during the examination because the students did not really understand the materials and prepare to study. There was another thing found during the observation. The learning media used were less attractive and could not motivate the students to study. Besides, there were still limited learning media containing character education.

Based on the explanation above, a solution is needed to solve the problem. It can be through the use of attractive, innovative, and the fun learning media so that the students are interested in using them. The use of those learning media can interest the students and improve the students' understanding (Gan, Menkhoff, $\&$ Smith, 2015). The learning media are also expected to be a tool for teachers to 
educate values to students because the process of students' character building is done through students' habituations (Murtini, 2016).

Electronic module or e-module is a new innovation from conventional module. The use of module in learning process is done because module has an advantage in giving many feedbacks so that the students can know their learning outcomes and complete mastery. Module is arranged with clear purposes, able to guide students to get success through reguler and flexible steps, and able to give students chances to fix their weaknesses, mistakes, or lacks based on the continuing evaluation (Nasution, 2006). Electronic module is aimed to improve students' interest in learning process and give easiness in using the module. Nurchali (2010) stated that the use of computer in learning process can give many and various learning experiences, improve learning motivation, and develop IT skill. The use of computer also gives positive effect in empowering students (Munadi, 2011). E-module is interactive so that it is possible to show pictures, audios, videos, animations, and completed with formative test/quiz which is possible to get feedbacks as soon as possible (Suarsana \& Mahayukti, 2013). So, the use of e-module in learning process can improve students' knowledge (Kim, Pederson, \& Balwind, 2011).

Accounting e-module integrated with character value can be a solution to solve the problem happened to the students at that vocational high school. The problem was the students' low understanding because the learning media used were not attractive so that the students were not confident in doing the examination, and then cheated. Thus, the use of this e-module is expected to be a tool for teachers to educate the value of honest character and improve the students' learning outcomes.

\section{METHOD}

This research was a quasiexperimental research. The research was conducted at Vocational High School "X" Surakarta City. This vocational high school is one of the favorite vocational high schools in Surakarta that offers several majors, such as, accounting, marketing, office administration, and multimedia. This school was chosen because it has implemented the 2013 curriculum in which the curriculum did not only emphasize the cognitive aspects of the students, but also the affective and psychomotor aspects so that one of the characteristics of this curriculum was an assessment of attitudes or characters. This school also had a qualified computer laboratory so that the students could use emodule freely and unlimitedly.

The population in this study was students of Vocational High School "X." The sample of this study was students of class $X$ Accounting. The study was conducted in two classes, namely $\mathrm{X}$ Accounting 1 and $X$ Accounting 2. In conducting the research, 32 students in class $\mathrm{X}$ Accounting 1 continued to use textbooks which were usually used in the learning process and did not use e-module integrated with character values. Then this class was called the control class. On the other hand, 32 students in class $\mathrm{X}$ Accounting 2 used e-module integrated with character values in the learning process. Then this class was called the experimental class.

The data were collected using tests and questionnaires. Tests were used to measure knowledge of the materials contained in the module. The form of the test was a multiple choice of 20 items. The steps taken for pretest and posttest data in determining the effectiveness of accounting e-module integrated with character values in improving the students' learning outcomes were as follows. 
The normality test was conducted to find out whether the data used in the study was normally distributed or not, that was carried out using the Kolmogrov-Smirnov Test with $\alpha=0.05$. The homogeneity test was conducted to find out whether the data obtained had a homogeneous variance or not, that was through the Levene's Test with $\alpha=0.05$. The t-test was conducted to determine the difference in the meanings significantly between the two classes significance level used was $\alpha=0.05$ and assisted by SPSS 22 program.

Questionnaires were used to measure the students' honesty behavior by using means of peer assessment. The type of questionnaire used in the study was a closed questionnaire with 15 questions. The formulation of the questionnaire was based on a predetermined honesty indicator that was not lying for personal interests or the interests of others, saying actual facts or events, rejecting those that were not his rights, not breaking the rules, claiming wrongdoing, not using other people's goods without permission, giving the rights of others, not bestowing their own mistakes on others (Widayanti, 2009). Scoring was based on a Likert scale with a score range of 1 to 4 . The selection of a 4point Likert scale was based on consideration: (1) facilitating respondents in the selection because they could distinguish each assessment point, (2) being easy to use and understand respondents (Sugiyono, 2015), (3) avoiding respondents in choosing "neutral" answers. Quantitative data of the questionnaire results were converted into qualitative data by using a qualification scale.

\section{RESULTS AND DISCUSSION Results}

It is found that the significance value of the normality test of pretest and posttest data in the experimental and control class was more than $\alpha(0.2>0.05)$. This showed that the cognitive value between the experimental and control class was normally distributed, whether it was in the pretest or posttest. It is found that the significance value of Levene's Test of the pretest data was 0.535 . The value was more than 0.05 so that the cognitive value in the pretest between the experimental and control class had the homogeneous variance. The significance value of the posttest data was 0.975 so that it could be concluded that the cognitive value in the posttest between the experimental and control class had the homogeneous variance.

Table 2. Scores of Pretest and Posttest

\begin{tabular}{cccccc}
\hline Data & Class & N & Mean & $\begin{array}{c}\text { Std. } \\
\text { Deviation }\end{array}$ & $\begin{array}{c}\text { Std. Error } \\
\text { Mean }\end{array}$ \\
\hline Pretest & Experimental & 32 & 62.97 & 10.149 & 1.794 \\
& Control & 32 & 66.41 & 9.179 & 1.623 \\
Posttest & Experimental & 32 & 81.25 & 8.424 & 1.489 \\
& Control & 32 & 75.94 & 8.370 & 1.480 \\
\hline
\end{tabular}

\section{Effectiveness Test}

In this research, effectiveness test and hypothesis test used t-test. Hypothesis testing with t-test was used to test the effectiveness of accounting e-module integrated with character value.
Based on the Table 2, it could be seen the control class showed that the score of the learning outcomes was higher than the experimental class. On the other hand, it was necessary to prove whether there was a significant difference of the 
learning achievement between the

out Independent Sample Test (Table 3).

experimental and control class by carrying

Table 3. T-test of Pretest and Posttest

\begin{tabular}{cccccccc}
\hline Data & \multicolumn{2}{l}{$\begin{array}{c}\text { Levene's Test for } \\
\text { Equality of } \\
\text { Variances }\end{array}$} & \multicolumn{1}{c}{ T-test for Equality of Means } \\
\cline { 2 - 8 } & $\mathbf{F}$ & Sig & $\mathbf{t}$ & df & $\begin{array}{c}\text { Sig (2- } \\
\text { tailed) }\end{array}$ & $\begin{array}{c}\text { Mean } \\
\text { Difference }\end{array}$ & $\begin{array}{c}\text { Std. Error } \\
\text { Difference }\end{array}$ \\
\hline Pretest & 0.389 & 0.535 & 1.421 & 62 & 0.160 & 3.438 & 2.419 \\
Posttest & 0.001 & 0.975 & 2.531 & 62 & 0.014 & 5.313 & 2.099 \\
\hline
\end{tabular}

Table 3 shows that there was no significant difference of the average score of the students' learning outcomes between the experimental and control class before using accounting e-module integrated with the character value. After ensuring that the experimental class and the control class had the same level of knowledge, the research could be continued by giving different treatments in the experimental and control class.

Accounting e-module integrated with character value was applied to the experimental class, while the control class still used learning media as usual, namely the text book and power point. The learning process in the experimental and control class lasted for four meetings. At the fourth meeting, the students were given a test to see the learning outcomes.

Based on Table 2, it could be seen that the posttest results of the experimental class were better than the control class. The results of this posttest indicated an increase between the experimental and control class from the previous one.

The obtained posttest result was then tested using Independent Sample Test to prove whether there was significant difference of the learning outcomes in the experimental and control class. The result showed that the students at experimental class had better learning outcomes than the students at control class.

\section{Result of Questionnaire}

The questionnaire contains 15 questions which are arranged based on honesty indicators, given at the end of the meeting. The question is about whether students do the assignments themselves, do students always report data in accordance with the facts in the field, do students include data sources when making a report, are students able and confident when explaining the results of their work, whether students ask permission before using goods that do not belong to them, and whether students prefer to be honest during the exam rather than getting high scores but the results of cheating.

The results of the questionnaire in the experimental class using integrated emodule accounting character values indicate that achieving honesty for all questions is included in the "excellent" qualification. This shows that all experimental class students have realized the importance of being honest and have shown honest behavior in accounting learning activities. In the control class that does not use an integrated e-module accounting character values indicate the average level of achievement with a "good" qualification.

In more detail, out of 15 questions there is one achievement with "very good" qualifications, namely in question number 7: my friend understands that cheating is an act of lying to oneself. This shows that 
the control class students understand and realize that cheating is an act of lying to themselves. In addition, there is one achievement with "sufficient" qualifications, namely in question number 14: my friend does not deliver bad test scores to his parents. This shows that some students are not open to their parents when they obtain unsatisfactory test scores. The remaining 13 questions are included in the "good" qualification. The results of the questionnaire analysis showed that the level of achievement of honesty in the experimental class students was better than the control class.

\section{Discussion}

The experimental test to find out the effectiveness of the use of accounting emodule integrated with character value was conducted by giving different treatment to experimental class and control class, whereas the students in the experimental class were given learning treatment by using accounting e-module integrated with character value. On the other hand, the students in the control class were given treatment by using the textbook that they usually used in the learning process and the power point without using accounting e-module integrated with character value.

It was found that there was significant difference of the students' learning outcomes between experimental class and control class. The result of the effectiveness test of the posttest can be seen at Table 3, while the data of the posttest result in Table 2 showed that the students' learning outcomes average at experimental class was higher than at control class can be linear with the result of the effectiveness test showing that there was difference at those two classes. The linearity ot those two test results showed that the use of accounting e-module integrated with character value was effective to improve the students' learning outcomes. The learning steps using the accounting e-module of the services company started with an explanation of the material by the teacher and gave some questions to the students. This activity aimed to see the extent of the students' understanding of the material. In addition, this activity was to provoke the students' curiosity.

The next step taken by the teacher was to divide the students into groups of 4 to 5 members. Each group member had the task of studying the material contained in the e-module and explaining it in front of the classroom. The use of e-module in the learning process would create the studentcentered learning (Lai, 2016). Besides, emodule made the learning process more innovative and fun because it featured the video of the material explanations, illustrated images and sample cases to make it easier for the students to understand the material (Muruganantham, 2015). It was in accordance with the research conducted by Woo (2011). Woo (2011) found that electronic module was more satisfying and enriching the students' learning experiences when compared to printed module. Besides, e-module was very effective to improve the students' ability in understanding materials (Wolla, 2017). The result of their research showed that there was positive and significant influence from the result of the pretest and posttest in the learning process using emodule.

The learning process in the control class continued as usual. The students used textbooks and the teacher explained the material using the power point. At the beginning of the teacher's explanation of the material, all students focused on paying attention to the teacher. When the learning had been going on for more than one hour, some students had begun not to focus on the learning. The students who sat in the back began not to pay attention to the teacher and talked to their peers, some students began to get sleepy and some were secretly playing mobile phones. At the control class, the learning became a teacher center learning so that not all 
students actively participated in seeking information and constructing it into an understanding. Therefore, the students' understanding of the material and learning outcomes at the control class was not as good as at the experimental class using the e-module.

Accounting e-module integrated with character values explicitly gave rise to honesty character values. This character value was in accordance with the characteristics of the accounting material which must be honest in reporting financial data. Thus, a financial report could be produced that described the financial condition of a business entity and became a tool for the company in making financial decisions. Accounting learning could be a means to develop honesty character, for example when making the company's financial report, it was forbidden to increase profits in order to obtain bank credit or attract investors to invest in the company. The company was also forbidden to reduce profits so that the taxes were paid less. Through the characteristics of the accounting material, it could be embedded honesty values in students.

Learning activities using e-module facilitated the students to be able to practice honesty in the learning activities. In the e-module, there was a video about the importance of being honest in making a financial report or being honest in everyday life. In addition, there were examples of cases related to honesty and reflection questions so that the students could write down their feelings after watching and reading stories about honesty and how they should behave in order to be honest. In the learning process, the teacher also familiarized the students to write the sources of the data on each task or report including documentation evidences which aimed to get the students used to speak by data. Activities such as watching video cases, answering reflection questions, writing sources of data and documentary evidences on each report could foster honesty behavior in students.

At the end of the meeting, the students were given questionnaire about value of honesty characters contained in the module. The result of the questionnaire at the experimental class showed that after using accounting e-module integrated with character value, the achievement level of honesty based on honesty indicators was in the very good category. It meant that the students at experimental class has showed honest behaviors in the indicators and practiced honest behaviors in accounting learning process. Wilujeng, Setiawan, \& Liliasari (2010) stated that the students' characters can be formed through the learning process. Inquiry standards, content standards, process standards, and assessment standards must be fulfilled in the learning process so that the expected learning objectives can be achieved. Emodule used in the learning process has been in accordance with and fulfilled those standards so that the expected learning objectives could be achieved. It was proven with the students' improved learning outcomes, and the achievement level of honesty character was in the very good category.

The achievement level of the students' honesty character at control class was in the good category. In the learning process, the students studied by using the textbook and power point which did not contain honesty character. The learning media did not facilitate the students to practice honesty values so that the students did not know the importance of being honest, the impacts of dishonest behavior, the advantages of being honest, and how to behave honestly. Although the achievement level of honesty character was in the good category, it could be maximized if the students were given the learning media contained character value.

Another research about the implementation of character education was conducted by Skaggs \& Bodenhorn (2006). The research aimed to find out the 
relationship between the implementation of character education on students' behaviors and learning outcomes. In the result of the research, character education did not significantly influence the students' learning achievement. In the research of Harrington, Giles, \& Hoyle (2001) about the evaluation of character education on high school students in America, it was found out that the program of character education did not significantly influence the students' behaviors. The results of those two researches showed that the effort to instill character education had to be done by teachers and environments. They had important roles to instill character education. Schools must strive to create a conducive and integrated environment between academic communities, parents, and communities so that process of character education can be carried out well and achieve the desired goals. Roles of social control and continuing evaluation are also needed to be done to keep monitoring changes of students' behaviors in a positive direction.

\section{CONCLUSION}

Accounting e-module integrated with character value was effective to improve the students' learning outcomes and honesty. The result of the research showed that the significance value in the effectiveness test of experimental class and control class was $0.014<0.05$. The average score of the cognitive ability at experimental class was 81.25 , while the average score of cognitive ability at control class was 75.94. The achievement of honesty aspect at experimental class was in the very good category, while the achievement of honesty aspect at control class was in the good category. It might be suggested to develop and implement such e-module that integrate character value in practice.

\section{ACKNOWLEDGEMENT}

Thanks to Vocational High School "X" at Surakarta for giving the researchers the opportunity to conduct this research.

\section{REFERENCES}

Agung, A. A. G. (2010). Evaluasi Pendidikan. Singaraja: Undiksha.

Gan, B., Menkhoff, T., \& Smith, R. (2015). Enhancing students' learning process through interactive digital media: New opportunities for collaborative learning. Computers in Human Behaviour, 51(Part B), 652663. doi: 10.1016/j.chb.2014.12.048.

Harrington, N. G., Giles, S. M., \& Hoyle, R. H. (2001). Evaluation of the all Stars character education and problem behavior prevention program: effects on mediator and outcome variables for middle school students. Health Education \& Behavior, 28(5), 533-546. doi: $10.1177 / 109019810102800502$.

Kesuma, D., Trianta, C., \& Premana, J. (2012). Pendidikan karakter, kajian teori dan praktik sekolah. Bandung: Remaja Rosdakarya.

Kim, H. J., Pederson, S., \& Baldwin, M. (2011). Improving user satisfaction via a case-enhanced e-learning environment. Education + Training, 54(3), 204-218. doi: 10.1108/00400911211210305.

Lai, C. (2016). Integrating e-books into sciences teaching by preservice elementary school teachers. Journal of Educational in Science: Environtment and Health (JESEH), 2(1), 57-66. 
Mahendra, D. (2013). Pengembangan Buku Digital Interaktif (BUDIN) berbasis adobe creative suite pada materi genetika di SMK. Semarang: UNNES.

Munadi, S. (2011). Pengembangan modul pembelajaran konstruktivistik kontekstual berbantuan komputer dalam matadiklat pemesinan. Jurnal Pendidikan Vokasi, 1(1), 51-67.

Murtini, W. (2016). Implementasi model "GEPPRAK" dalam pembelajaran kewirausahaan untuk meningkatkan minat berwirausaha di sekolah menengah kejuruan. Jurnal Pedidikan Vokasi, 6(3), 335-345. doi: 10.21831/jpv.v6i3.11176.

Muruganantham. (2015). Mengembangkan paket e-konten dengan menggunakan ADDIE model. International Journal of Applied Research, 1(3), 52-58.

Nasution, S. (2006). Berbagai pendekatan dalam proses belajar mengajar. Bumi aksara: Jakarta.

Nurchali. (2010). Pengaruh media pembelajaran dengan teknologi informasi dalam pembelajaran kimia terhadap peningkatan hasil belajar mahasiswa. Jurnal Pendidikan dan Kebudayaan, 16(6), 648-658. doi: 10.24832\%2Fjpnk.v16i6.493.

Skaggs, G., \& Bodenhorn, N. (2006). Relationships between implementing character education, student behaviour, and student achievement. Journal of Advanced Academics,
18(1), 333-345. doi: 10.4219/jaa2006-345.

Suarsana, I. M., \& Mahayukti, G. A. (2013). Pengembangan e-module berorientasi pemecahan masalah untuk meningkatkan keterampilan berpikir kritis mahasiswa. Jurnal Pendidikan Indonesia, 2(2), 264275.

doi:

undiksha.v2i2.2171.

10.23887/jpi-

Sugiyono. (2015). Metode penelitian pendidikan: Pendekatan kuantitatif, kualitatif, dan R\&D. Alfabeta: Bandung.

Widayanti, E. Y. (2009). Keefektifan Model Susan Loucks-Horsley untuk pendidikan karakter melalui pembelajaran sains di tingkat sekolah dasar. Yogyakarta: Universitas Negeri Yogyakarta.

Wijaya, A. H. (2011). Kejujuran dalam pendidikan. Jurnal Innovatio, 9(1), 17-24.

Wilujeng, I., Setiawan. A., \& Liliasari. (2010). Kompetensi IPA terintegrasi melalui pendekatan keterampilan proses mahasiswa S-1 Pendidikan IPA. Jurnal Cakrawala Pendidikan, 3(3), 150-163.

doi: $10.21831 /$ cp.v3i3.363.

Wolla, S. (2017). Evaluating the effectiveness of an online module for increasing financial literacy. Social Studies Research and Practice, 12(2), 154-167.

doi: 10.1108/SSRP-04-2017-0014. 
Woo, T. K. (2011). Developing quality learning materials for effective teaching and learning in an ODL environment: Making the jump from print moduules to online modules. Asian Association of Open Universities Journal, 6(1), 51-58.
Zulkhairi, T. (2011). Membumikan karakter jujur dalam pendidikan di Aceh. Jurnal Ilmiah Islam Futura, 11(1), 104-115. doi: 10.22373/jiif.v11i1.65. 